\title{
Avaliação de dois métodos de extração de DNA de material parafinado para amplificação em PCR
}

\section{Evaluation of two methods of DNA extraction from paraffin-embedded material for PCR amplification}

Luciana Estevam Simonato ${ }^{1}$, José Fernando Garcia ${ }^{2}$, Cáris Maroni Nunes ${ }^{3}$, Glauco Issamu Miyahara ${ }^{4}$

\section{unitermos DNA}

Reação em cadeia da polimerase Tecido parafinado

\section{resumo}

Introdução: Diversos métodos para extração de DNA a partir de tecidos biológicos inclusos em parafina encontram-se descritos na literatura, sendo o sucesso desse procedimento de grande importância para a realização de métodos moleculares de diagnóstico empregando a reação em cadeia da polimerase (PCR). Objetivo: Este estudo avaliou dois métodos de extração de DNA de material parafinado, visando à amplificação do DNA genômico pela técnica da PCR. Material e método: Foram utilizadas 35 amostras de casos de carcinoma epidermóide de assoalho bucal diagnosticados e tratados no Centro de Oncologia Bucal da Universidade Estadual Paulista (Unesp). Os métodos de extração de DNA avaliados incluíram: 1. digestão com proteinase K seguida por purificação com Chelex $100^{\circledR}$ (BioRad); e 2. sistema QIAamp DNA minikit ${ }^{\circledR}$ (Qiagen). O DNA obtido foi quantificado por espectrofotometria e amplificado pela técnica da PCR, utilizando-se oligonucleotídeos iniciadores para betaglobina. Resultados: A concentração de DNA obtido do material extraído com o primeiro método apresentou média de 120,62 $\mathrm{ng} / \mu \mathrm{l} \mathrm{com}$ razão entre as leituras das absorbâncias $260 / 280$ variando de 0,8 a 1,41. Para as amostras extraídas com o segundo procedimento, o rendimento médio foi de $67,38 \mathrm{ng} / \mu \mathrm{l}$, no entanto a razão 260/280 variou entre 1,11 e 2,53. O material foi submetido à PCR e, das 35 amostras extraídas com cada método, respectivamente, 29 e 30 apresentaram sinal positivo. Conclusão: Os dois métodos utilizados para obtenção de DNA de material parafinado apresentaram desempenho semelhante, revelando que ambos têm potencial para auxiliar na prática da biologia molecular diagnóstica, assim como no estudo diagnóstico retrospectivo em material parafinizado.

\begin{abstract}
Background: There are several methods for DNA extraction from formalin-fixed paraffin-embedded tissues reported in the literature. High success rate on this procedure is important for the use of molecular diagnostic methods based on the polymerase chain reaction (PCR). Objective: Two methods of DNA extraction from paraffin-embedded samples were tested aiming at PCR amplification of genomic DNA. Material and method: Thirty-five samples were obtained from patients with squamous cell carcinoma of mouth floor treated at the Oral Oncology Center in Universidade Estadual Paulista. The DNA extraction methods included: 1. proteinase $K$ digestion followed by Chelex $100^{\circledR}$ (BioRad) purification and 2. QIAamp DNA minikit ${ }^{\circledR}$ system (Qiagen). Purified DNA was quantified by spectrophometry and a beta-globin gene fragment was amplified using PCR. Results: The DNA concentration from samples applied to the first method presented an average of $120.62 \mathrm{ng} / \mu \mathrm{l}$ and absorbance ratio $260 / 280$ varying between 0.8 and 1.41. From the samples extracted using the second procedure, the mean DNA concentration was $67.38 \mathrm{ng} / \mu \mathrm{l}$, with absorbance ratio varying between 1.11 and 2.53. DNA samples were submitted to PCR and from 35 samples extracted with both methods, respectively, 29 and 30 were successfully amplified for the beta-globin gene. Conclusion: Both methods used to obtain genomic DNA from formalin-fixed paraffin-embedded tissues presented similar performance, revealing their potential to be included in diagnosis of molecular biology, as well as in retrospective studies using archived paraffin-embedded samples.
\end{abstract}

abstract

1. Mestranda em Odontologia, área de Estomatologia, Departamento de Patologia e Propedêutica Clínica, Faculdade de Odontologia de Araçatuba da Universidade Estadual Paulista (Unesp). 2. Professor-assistente-doutor do Departamento de Apoio, Produção e Saúde Animal; responsável pelo Laboratório de Bioquímica e Biologia Molecular Animal da Faculdade de Odontologia e Curso de Medicina Veterinária de Araçatuba (Unesp).

3. Professora-assistente-doutora do Departamento de Apoio, Produção e Saúde Animal da Faculdade de Odontologia e Curso de Medicina Veterinária de Araçatuba (Unesp).

4. Professor-assistente-doutor do Departamento de Patologia e Propedêutica Clínica da Faculdade de Odontologia de Araçatuba (Unesp).

Trabalho realizado no Laboratório de Bioquímica e Biologia Molecular Animal da Faculdade de Faculdade de Odontologia e Curso de Medicina Veterinária de Araçatuba (Unesp) e no Centro de Oncologia Bucal da Faculdade de Odontologia de Araçatuba (Unesp).

Apoio financeiro: Fundação para o Desenvolvimento da Unesp (Fundunesp) (00017/05). 


\section{Introdução}

As técnicas de otimização de extração de DNA para utilização na reação em cadeia pela polimerase (PCR) permitem a investigação diagnóstica em diferentes amostras biológicas, mesmo quando o DNA está presente em pequenas quantidades. Resquícios de saliva, esfregaço bucal, sangue, bulbos capilares, tecidos incluídos em parafina, ossos, gotas de esperma, entre outros, podem fornecer informações importantes, desde que analisados de forma adequada $^{(1,4)}$.

Rotineiramente, amostras de tecidos são removidas do corpo humano para análise visando diagnóstico de doenças, sendo os fragmentos desses materiais fixados em formol, incluídos em parafina e armazenados nos laboratórios. Esses espécimes representam importante fonte de material biológico para pesquisa ${ }^{(11)}$. $\mathrm{O}$ aperfeiçoamento dos métodos de extração de DNA a partir de tecido parafinado, de forma a torná-los de execução simples e de menor custo, facilita enormemente a utilização desses materiais em estudos retrospectivos, trazendo grande contribuição para a investigação da etiologia e a epidemiologia das patologias ${ }^{(13,19)}$.

Segundo Kullmann et al. ${ }^{(14)}$, Lehmann e Kreipe ${ }^{(15)}$ e Liu et al.(16), o fator que tem maior influência no sucesso da amplificação do DNA obtido de material parafinado é o grau de fragmentação do DNA presente. Falhas também podem ser atribuídas ao efeito direto do fixador e ao tempo e/ou temperatura de fixação utilizada no processamento do material.

Existem na literatura vários protocolos para a extração de DNA a partir de material parafinado, sendo sua obtenção de grande importância para a realização de estudos na área da biologia molecular ${ }^{(7,17,18,20)}$.

Neste trabalho apresentamos os resultados da extração de DNA de 35 amostras de tecido de casos de carcinoma epidermóide de assoalho bucal que haviam sido fixadas em formol a $10 \%$ e conservadas em blocos de parafina, empregando-se dois métodos de extração de DNA. Os métodos avaliados incluíram digestão por proteinase $\mathrm{K}$ seguida por purificação com Chelex $100^{\circledR}$ e o sistema QIAamp DNA minikit ${ }^{\circledast}$.

\section{Material e método}

Foram utilizadas 35 amostras de tecido provenientes de casos de carcinoma epidermóide de assoalho bucal, fixados em formol a $10 \%$ e embebidos em parafina, diagnosticados e tratados no Centro de Oncologia Bucal (Unidade Auxiliar) da Faculdade de Odontologia de Araçatuba (Universidade Estadual Paulista [UNESP]). Após a limpeza dos blocos e a remoção da parafina externa, foram coletados $25 \mathrm{mg}$ de tecido de cada bloco, utilizando-se micrótomo limpo, com navalhas descartáveis. Após o corte, as fatias foram acondicionadas em tubos de $1,5 \mathrm{ml}$ e mantidas à temperatura ambiente até o momento da extração. Os procedimentos laboratoriais foram realizados por um único pesquisador.

\section{Preparo dos cortes}

Antes da extração do DNA, os cortes passaram pelo processo de desparafinização, sendo que cada método requereu procedimentos distintos.

Para purificação com Chelex $100^{\circledast}$ foram adicionados $100 \mu$ de solução Tween 20 a 0,5\% nos tubos contendo os cortes. Após homogeneização, os tubos foram aquecidos a $90^{\circ} \mathrm{C}$ por 10 minutos e resfriados para $55^{\circ} \mathrm{C}$ utilizando-se o termociclador.

Para purificação com QIAamp DNA minikit ${ }^{\circledR}$ foram adicionados $1.200 \mu \mathrm{l}$ de xilol, agitando-se por 15 segundos. Em seguida, os tubos foram centrifugados a 14.000 rotações por minuto (rpm) durante cinco minutos. O sobrenadante foi desprezado e $1.200 \mu \mathrm{l}$ de etanol foram adicionados ao sedimento. Os tubos foram agitados por 15 segundos e centrifugados a $14.000 \mathrm{rpm}$ durante cinco minutos. Esse procedimento foi repetido e, ao final, os tubos com as tampas abertas foram colocados em centrífuga a vácuo a $37^{\circ} \mathrm{C}$ durante 15 minutos, objetivando a evaporação do etanol remanescente.

\section{Extração com Chelex 100 $^{\circledR}$ (BioRad)}

O protocolo para extração de DNA com Chelex $100^{\circledR}$ foi baseado no método descrito por Coombs et al.(9). Em cada tubo foi adicionado $1 \mu \mathrm{l}$ de proteinase $\mathrm{K}(20 \mathrm{mg} / \mathrm{ml})$, sendo as amostras incubadas em banho-maria a $55^{\circ} \mathrm{C}$, durante três horas, e agitadas gentilmente a cada hora. Após esse período, a cada tubo foram adicionados $100 \mu \mathrm{l}$ de Chelex $100^{\circledR}$ a $5 \%$ (diluído em solução de Tris $10 \mathrm{mM} \mathrm{e}$ EDTA $1 \mathrm{mM}$ ), sendo os mesmos aquecidos a $99^{\circ} \mathrm{C}$ durante 10 minutos e agitados gentilmente após o término do aquecimento. Seguiu-se a centrifugação a $10.600 \mathrm{rpm}$ durante 15 minutos. Os tubos foram novamente aquecidos a $45^{\circ} \mathrm{C}$ por cinco minutos e, posteriormente, foram adicionados $100 \mu \mathrm{l}$ de clorofórmio. Realizou-se centrifugação a 10.600 rpm durante 15 minutos, recuperando-se o sobrenadante contendo o DNA em tubos limpos, que foram armazenados a $20^{\circ} \mathrm{C}$ negativos. 


\section{Extração com QIAamp DNA minikit ${ }^{\circledR}$ (Qiagen)}

O protocolo para extração de DNA a partir de material parafinado com o sistema comercial QIAamp DNA minikit ${ }^{\circledR}$ foi realizado de acordo com as normas do fabricante.

Em cada tubo foram adicionados $180 \mu \mathrm{l}$ de Buffer ATL (Tissue Lysis Buffer), além de $20 \mu \mathrm{l}$ de proteinase K. Após homogeneização, as amostras foram incubadas em banhomaria a $55^{\circ} \mathrm{C}$, durante três horas, e agitadas gentilmente a cada hora. Após esse período, adicionaram-se a cada tubo $200 \mu \mathrm{l}$ de Buffer AL (fornecido pelo fabricante), sendo os mesmos aquecidos a $70^{\circ} \mathrm{C}$ durante 10 minutos para a inativação da proteinase residual. Em seguida, foram adicionados $200 \mu$ de etanol, agitando-se durante 15 segundos e centrifugando brevemente.

A solução resultante foi transferida para o dispositivo da coluna QIAamp DNA minikit ${ }^{\circledast}$ e centrifugada a 8.000 rpm por um minuto. $\mathrm{O}$ dispositivo com a coluna foi removido do tubo e recolocado em um tubo limpo. Foram adicionados $500 \mu \mathrm{l}$ de Buffer AW1 (Wash Buffer 1) ao dispositivo com a coluna, que foram centrifugados a $8.000 \mathrm{rpm}$ por um minuto. $\mathrm{O}$ procedimento de lavagem foi repetido com $500 \mu \mathrm{l}$ de Buffer AW2 (Wash Buffer 2), seguido de centrifugação a 14.000 rpm durante três minutos.

O DNA extraído da coluna foi eluído pela adição de 100 $\mu \mathrm{l}$ de Buffer $\mathrm{AE}$ (fornecido pelo fabricante). Primeiramente foram adicionados $50 \mu \mathrm{l}$, aguardando-se um minuto e centrifugando-se a $8.000 \mathrm{rpm}$ durante um minuto. Em seguida, $50 \mu \mathrm{l}$ de Buffer AE foram adicionados, aguardando-se cinco minutos e centrifugando-se a $8.000 \mathrm{rpm}$ por um minuto, após as amostras terem sido transferidas do dispositivo para tubo de recuperação. As mesmas foram armazenadas a $-20^{\circ} \mathrm{C}$.

\section{Quantificação e amplificação do DNA}

A quantidade e a pureza do DNA genômico foram determinadas por densidade óptica em espectrofotômetro (NanoDrop ${ }^{\circledR}$ ND-1000 UV-Vis). O DNA genômico foi amplificado utilizando-se a PCR com iniciadores para o gene constitutivo da betaglobina (268 pares de bases [pb]). A seqüência dos iniciadores utilizados foi descrita por Bell et al. ${ }^{(2)}$, sendo $\mathrm{GH} 20$ 5'-GAAGAGCCAAGGACAGGTAC-3 e PC04 5'-CAACTTCATCCACGTTCACC- 3'. A reação foi realizada em um termociclador (PTC-100, MJ Research, Inc., Watertown, MS, EUA) adicionando-se os seguintes reagentes a um tubo de 0,2 ml: $1 \mathrm{U}$ de Taq DNA polimerase
(Invitrogen Life Technologies ${ }^{\circledR}$, Brasil); $2.5 \mu$ de tampão de PCR 10X (10 mM de Tris- $\mathrm{HCl}$ pH 8 e $50 \mathrm{mM}$ de $\mathrm{KCl}$ - Invitrogen Life Technologies ${ }^{\circledast}$, Carlsbad, CA, EUA), 4mM de $\mathrm{MgCl}_{2}$ (Invitrogen Life Technologies ${ }^{\circledR}$, Carlsbad, CA, EUA), 0,25 mM de dNTP (desorribonucleotídeo 5'-trifosfatado - dATP, dCTP, dGTP e dTTP - GE Healthcare, Piscataway, $\mathrm{NJ}$, EUA), 15 pmol de cada oligonucleotídeo (GH20/PCO4 - Invitrogen Life Technologies ${ }^{\circledR}$, Brasil) e 10,9 $\mu$ de água ultrapura q.s.p. (Invitrogen Life Technologies ${ }^{\mathrm{TM}}$, Carlsbad, CA, EUA). Após a mistura, foram adicionados $5 \mu \mathrm{l}$ do DNA de cada amostra, totalizando volume final de $25 \mu$ l.

Os ciclos de temperatura consistiram de desnaturação inicial a $94^{\circ} \mathrm{C} / 10$ minutos, seguida de 40 ciclos de desnaturação a $94^{\circ} \mathrm{C} / 1$ minuto, anelamento a $65^{\circ} \mathrm{C} / 1$ minuto e extensão a $72^{\circ} \mathrm{C} / 2$ minutos, seguidos de extensão final a $72^{\circ} \mathrm{C} / 7$ minutos. O sucesso da amplificação do DNA foi verificado por eletroforese em gel de agarose a $2 \%$, corado em brometo de etídio, visualizado sob luz ultravioleta e documentado com auxílio do sistema Kodak Digital Science 1D.

\section{Análise estatística}

A análise estatística foi realizada por meio do teste $t$ pareado, com nível de significância de $1 \%$.

\section{Resultados}

A quantidade e a pureza do DNA genômico obtido por ambas as técnicas avaliadas foram satisfatórias para a realização da PCR. Houve diferença estatisticamente significativa entre os grupos, tanto na quantidade $(p=0,0003)$ como na pureza $(p<0,0001)$ do DNA obtido.

A concentração de DNA obtido do material extraído com o Chelex $100^{\circledR}$ apresentou média de 120,62 ng/ $\mu \mathrm{l}$ com razão entre as leituras das absorbâncias 260/280 entre 0,8 e 1,41. Para as amostras extraídas com o QIAamp DNA minikit ${ }^{\circledR}$ o rendimento médio foi de $67,38 \mathrm{ng} / \mu \mathrm{l}$, no entanto a razão entre as leituras $260 / 280$ variou entre 1,11 e 2,53 (Tabela).

A amplificação por PCR do gene da betaglobina a partir do DNA genômico obtido pelos dois métodos de extração é apresentada nas Figuras 1 e 2. Das 35 amostras processadas para extração do DNA, 29 (82,85\%) foram positivas quando submetidas à extração com Chelex $100^{\circledR}$ e 30 (85,7\%) pelo QIAamp DNA minikit ${ }^{\circledR}$. 
Tabela

Amostras

Chelex 01

Chelex 02

Chelex 03

Chelex 04

Chelex 05

Chelex 06

Chelex 07

Chelex 08

Chelex 09

Chelex 10

Chelex 11

Chelex 12

Chelex 13

Chelex 14

Chelex 15

Chelex 16

Chelex 17

Chelex 18

Chelex 19

Chelex 20

Chelex 21

Chelex 22

Chelex 23

Chelex 24

Chelex 25

Chelex 26

Chelex 27

Chelex 28

Chelex 29

Chelex 30

Chelex 31

Chelex 32

Chelex 33

Chelex 34

Chelex 35

Média

Desvio padrão

Quantidade e pureza do DNA genômico obtido com duas técnicas de extração (Chelex $100^{\circledR} \mathrm{e}$ QIAamp DNA minikit ${ }^{\circledR}$ )

\begin{tabular}{|c|c|c|c|c|}
\hline $\mathrm{ng} / \mathrm{ul}$ & $260 / 280$ & Amostras & $\mathrm{ng} / \mathrm{ul}$ & $260 / 280$ \\
\hline 275,54 & 1,27 & QIAamp 01 & 88,33 & 1,89 \\
\hline 42,08 & 0,94 & QIAamp 02 & 61,83 & 1,71 \\
\hline 58,42 & 0,91 & QIAamp 03 & 68,13 & 1,81 \\
\hline 38,89 & 1,01 & QIAamp 04 & 45,03 & 2,02 \\
\hline 103,53 & 0,95 & QIAamp 05 & 95,22 & 1,86 \\
\hline 199,40 & 1,07 & QIAamp 06 & 72,59 & 2,08 \\
\hline 243,04 & 1,17 & QIAamp 07 & 33,92 & 2,26 \\
\hline 147,97 & 1,13 & QIAamp 08 & 66,56 & 1,94 \\
\hline 200,20 & 1,08 & QIAamp 09 & 87,16 & 1,96 \\
\hline 53,52 & 0,93 & QIAamp 10 & 59,56 & 1,85 \\
\hline 156,36 & 1,07 & QIAamp 11 & 115,89 & 2,08 \\
\hline 174,07 & 1,01 & QIAamp 12 & 13,76 & 2,53 \\
\hline 215,59 & 1,17 & QIAamp 13 & 118,54 & 1,92 \\
\hline 236,88 & 1,26 & QIAamp 14 & 90,96 & 1,84 \\
\hline 99,31 & 1,01 & QIAamp 15 & 92,72 & 1,98 \\
\hline 179,03 & 1,08 & QIAamp 16 & 35,05 & 1,78 \\
\hline 52,71 & 0,92 & QIAamp 17 & 28.06 & 1.91 \\
\hline 61,17 & 0,8 & QIAamp 18 & 25,21 & 2,19 \\
\hline 26,75 & 0,99 & QIAamp 19 & 13,33 & 1,92 \\
\hline 57,84 & 0,96 & QIAamp 20 & 196,34 & 2,07 \\
\hline 161,57 & 1,41 & QIAamp 21 & 92,98 & 1,85 \\
\hline 74,37 & 1,14 & QIAamp 22 & 7,82 & 1,42 \\
\hline 94,78 & 1,23 & QIAamp 23 & 20,25 & 2,43 \\
\hline 54,93 & 1,09 & QIAamp 24 & 29,9 & 2,09 \\
\hline 187,76 & 1,34 & QIAamp 25 & 66,6 & 1,9 \\
\hline 109,5 & 1,24 & QIAamp 26 & 51,37 & 1,56 \\
\hline 37,55 & 0,99 & QIAamp 27 & 30,5 & 1,62 \\
\hline 95,85 & 1,05 & QIAamp 28 & 204,47 & 1,93 \\
\hline 119,03 & 1,13 & QIAamp 29 & 27,16 & 1,8 \\
\hline 97,09 & 1,14 & QIAamp 30 & 61,02 & 2,06 \\
\hline 222,36 & 1,23 & QIAamp 31 & 70,82 & 2,05 \\
\hline 85,71 & 1,18 & QIAamp 32 & 79,81 & 2,1 \\
\hline 46,54 & 0,9 & QIAamp 33 & 91,84 & 1,11 \\
\hline 55,71 & 0,99 & QIAamp 34 & 43,04 & 2,4 \\
\hline 156,82 & 1,28 & QIAamp 35 & 72,47 & 1,72 \\
\hline 120,62 & & & 67,38 & \\
\hline 70,57 & & & 44,59 & \\
\hline
\end{tabular}




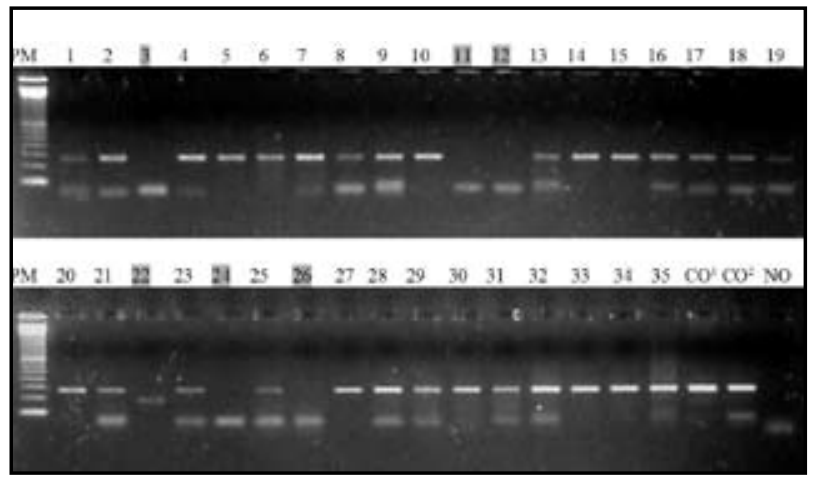

Figura 1 - Fotografia do gel de agarose a 2\% com resultado da amplificação do gene da betaglobina (268 pb) em 35 amostras parafinizadas de carcinoma epidermóide de assoalho bucal extraídas com o Chelex $100^{\circledR} . P M=$ peso molecular de $100 \mathrm{pb} ; \mathrm{CO}^{1}=$ controle (DNA extraído de sangue humano); $\mathrm{CO}^{2}=$ controle (DNA extraído de biópsia de condiloma acuminado); $\mathrm{NO}=$ controle (sem DNA).

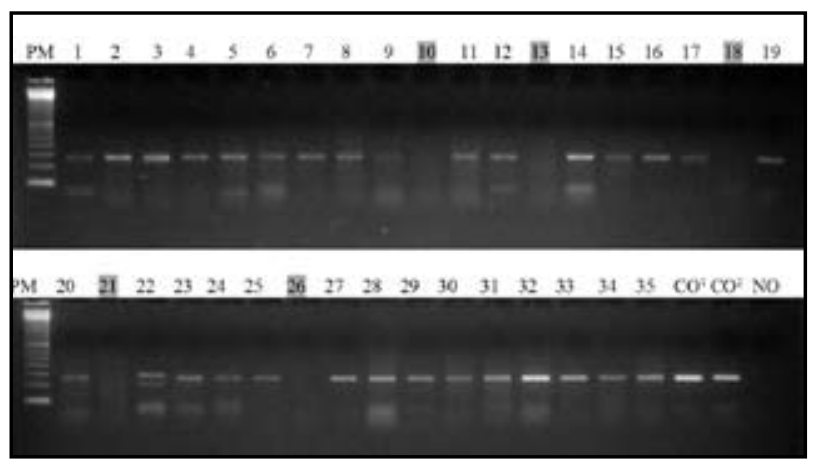

Figura 2 - Fotografia do gel de agarose a $2 \%$ com resultado da amplificação do gene da betaglobina (268 pb) em 35 amostras parafinizadas de carcinoma epidermóide de assoalho bucal extraídas com o QIAamp DNA minikit ${ }^{\circledR}$. PM = peso molecular de 100 pb; $C O^{1}=$ controle (DNA extraído de sangue humano); $C O^{2}=$ controle (DNA extraído de biópsia de condiloma acuminado); NO = controle (sem DNA).

\section{Discussão}

A fixação de tecidos com formol a 10\% é um método prático e eficiente para sua preservação, sendo, portanto, largamente utilizado em anatomia patológica. Contudo esse tipo de fixação resulta no enovelamento de proteínas nucleares, na formação de ligações entre proteínas e DNA e na fragmentação do DNA, o que dificulta a extração dessa classe de moléculas de tecidos fixados ${ }^{(12)}$. Além disso, vários outros passos podem influenciar a obtenção de amplificações positivas, a começar pela forma de obtenção dos cortes $^{(7)}$; a desparafinização, que além de poder ser opcional ${ }^{(8,17)}$ pode ser realizada através de calor ${ }^{(3,5,8)}$ ou lavagens com solventes, como xilo( ${ }^{(3,6,9)}$; o tempo de digestão em proteinase $K$ e a concentração desta no tampão de digestão(13,18). No nosso trabalho, todas as amostras utilizadas foram fixadas em formol a $10 \%$, seguindo protocolo de fixação de tecidos em rotina, além de terem sido desparafinadas e digeridas em proteinase $\mathrm{K}$ por três horas.
Mesmo assim, a maioria se mostrou positiva para o gene da betaglobina quando amplificada pela PCR.

Segundo Coombs et al.(9), os principais obstáculos à obtenção de DNA de material parafinado para amplificação por PCR são a remoção da parafina e a purificação do DNA. Dessa forma, em nosso estudo verificamos dois métodos de extração de DNA de material parafinado. O primeiro consistiu na purificação com Chelex $100^{\circledR}$ após desparafinização através de calor e digestão enzimática, enquanto no segundo método a purificação foi feita com QIAamp DNA minikit ${ }^{\circledR}$, após a remoção da parafina com xilol e a digestão enzimática das proteínas com proteinase K. Ambos os métodos descritos proporcionaram a obtenção do DNA, o que está de acordo com diversos trabalhos descritos na literatura $(9,10,12,17,20)$.

O bom desempenho de técnicas de isolamento de ácidos nucléicos a partir de tecidos parafinados em quantidade, pureza e integridade adequadas é uma fase essencial na prática da biologia molecular diagnóstica ${ }^{(3,21)}$. As técnicas utilizadas no presente trabalho mostraram que ambos os métodos de extração do DNA genômico utilizados apresentaram desempenho semelhante na obtenção de DNA em condições de ser amplificado por PCR, mesmo havendo diferença estatisticamente significativa na concentração e no grau de pureza das amostras obtidas com os dois métodos.

No nosso estudo obtivemos elevado sucesso na amplificação do DNA extraído com Chelex $100^{\circledR}$, já que $82,85 \%$ das amostras de DNA obtidas foram amplificadas por PCR, da mesma forma que Coombs et al..$^{(9)}$, De Lamballerie et al. ${ }^{(10)}$ e Sepp et al. ${ }^{(20)}$, que determinaram que o melhor método de extração de DNA de tecidos incluídos em parafina é aquele que utiliza o Chelex $100^{\circledR}$, no qual é feita a purificação com resinas quelantes após a desparafinização do material.

Chan et al. ${ }^{(6)}$ avaliaram métodos de extração de material parafinado para amplificação por PCR de DNA humano e viral. Os resultados mostraram que a taxa de amplificação mais alta do gene da betaglobina pela PCR ocorreu nas amostras extraídas pelo método fenol/clorofórmio. Por outro lado, o QIAamp DNA minikit ${ }^{\circledR}$ foi o mais eficiente para o DNA de HPV. No entanto, Bielawski et al. ${ }^{(3)}$ realizaram um estudo avaliando três métodos de desparafinização e três métodos de purificação de DNA de material parafinado, cujo resultado apresentou-se maior amplificação das amostras extraídas com o QIAamp DNA minikit ${ }^{\circledR}$, que apresentaram maior grau de pureza, à semelhança do resultado observado no nosso estudo.

Dessa forma, apesar de o segundo método ter se mostrado eficiente, de execução simples e de grande praticidade, apresenta restrição financeira, tendo em vista que o 
sistema apresenta elevado custo. Além disso, o método de extração de DNA com desparafinização através do calor e purificação com Chelex $100^{\circledR}$ não utiliza solvente orgânico, pois durante todo o processo utilizam-se apenas dois tubos plásticos para cada amostra, não sendo necessário transferir o sobrenadante inúmeras vezes como no método com o sistema, dessa forma diminuindo o consumo de reagentes, otimizando os procedimentos e reduzindo a possibilidade de contaminação das amostras.

\section{Conclusão}

Os dois métodos utilizados para obtenção de DNA de material parafinado neste estudo apresentaram desem- penho semelhante em condições locais, revelando que ambos os métodos descritos têm potencial para extrair DNA genômico de boa qualidade. No entanto, o Chelex $100^{\circledR}$ apresenta custo menos elevado, sendo uma alternativa viável para o uso de rotina.

\section{Agradecimentos}

À Fundação Coordenação de Aperfeiçoamento de Pessoal de Nível Superior (Capes), pelo apoio na concessão de bolsa de estudo, e à Fundação para o Desenvolvimento da Unesp (Fundunesp), pelo apoio financeiro (processo $\mathrm{n}^{\circ}$ 00017/05).

\section{Referências}

I. BAREA, J.A.;PARDINI, M.I.M.C.; GUSHIKEN,T. Extração de DNA de materiais de arquivo e fontes escassas para utilização em reação de polimerização em cadeia (PCR). Rev Bras Hematol Hemoter, v. 26, n. 4, p. 274-8I, 2004.

2. BELL, D.A. et al. Genetic risk and carcinogen exposure: a common inherited defect of the carcinogen-metabolism gene glutathione S-transferase MI (GSTMI) that increases susceptibility to bladder cancer. J Natl Cancer Inst, v. 85, n. I4, p. I I59-64, 1993.

3. BIELAWSKI, K. et al. The suitability of DNA extracted from formalin-fixed, paraffin-embedded tissues for double differential polymerase chain reaction analysis. Int J Mol Med, v. 8, n. 5, p. 573-8, 200 I.

4. BUENO, V. DNA e aperfeiçoamento das técnicas de extração. Rev Bras Hematol Hemoter, v. 26, n. 4, p. 233-4, 2004.

5. CAO,W. et al. Comparison of methods for DNA extraction from paraffin-embedded tissues and buccal cells. Cancer Detect Prev, v. 27, n. 5, p. 397-404, 2003.

6. CHAN, P.K. et al. Evaluation of extraction methods from paraffin wax embedded tissues for PCR amplification of human and viral DNA.J Clin Pathol, v. 54, n. 5, p. 401-3, 2001.

7. CHEN, B.; CLEJAN, S. Rapid preparation of tissue DNA from paraffin-embedded blocks and analysis by polymerase chain reaction.J Histochem Cytochem, v. 4I, n. 5, p. 765-8, 1993.

8. COATS, P.j. et al. Simplified procedures applying the polymerase chain reaction to routinely fixed paraffin-wax sections.) Clin Pathol, v. 44, n. 2, p. I I5-8, 1991.

9. COOMBS, N.J.; GOUGH, A.C.; PRIMROSE, J.N. Optimization of DNA and RNA extraction from archival formalin-fixed tissue. Nucleic Acids Res, v. 27, n. 16, p. el 2, 1999.

10. DE LAMBALLERIE, $X$. et al. Improved current methods for amplification of DNA from routinely processed liver tissue by PCR. J Clin Pathol, v. 47, n. 5, p. 466-7, 1994.

I I. FERNANDES, J.V. et al. Comparação de três protocolos de extração de DNA a partir de tecido fixado em formol e incluído em parafina. J Bras Patol Med Lab, v. 40, n. 3, p. |4|-6, 2004.

12. ISOLA, J. et al. Analysis of changes in DNA sequence copy number by comparative genomic hybridization in archival paraffin-embedded tumor samples. Am J Pathol, v. I 45, n. 6, p. I30I-8, 1994.

13. JACKSON, D.P. et al. Tissue extraction of DNA and RNA and analysis by the polymerase chain reaction.J Clin Pathol, v. 43, n. 6, p. 499-504, 1990.

14. KULLMAN, F. et al. A comparison of methods for DNA extraction from paraffin-embedded tissue for microsatellite instability analysis by PCR. Acta Biotech, v. 18, n. I, p. 77-83, 1998.

15. LEHMANN, U.; KREIPE, H. Real-time PCR analysis of DNA and RNA extracted from formalin-fixed and paraffin-embedded biopsies. Methods, v. 25, n. 4, p. 409-18, 2001.

16. LIU, L. et al. Rearrangement of the BCL-2 gene in follicular lymphoma. Detection by PCR in both fresh and fixed tissue samples. Diagn Mol Pathol, v. 2, n. 4, p. 24I-7, 1993.

17. MATIZONKAS, L.F. et al. Extração rápida de DNA para uso no diagnóstico histopatológico e estudos retrospectivos: comparação de quatro métodos. RPG Rev Pós Grad, v. 9, n. 2, p. |37-4|, 2002.

18. MESQUITA, R.A. et al. Avaliação de três métodos de extração de DNA de material parafinado para amplificação de DNA genômico pela técnica da PCR. Pesqui Odontol Bras, v. 15 , n. 4, p. 3|4-9, 2001 . 
19. PINTO, A.P.; VILLA, L.L. A spin cartridge system for DNA extraction from paraffin wax-embedded tissues. Mol Pathol, v. 5 I, n. I, p. 48-9, 1998

20. SEPP, R. et al. Rapid techniques for DNA extraction from routinely processed archival tissue for use in PCR. J Clin Pathol, v. 47, n. 4, p. 318-23, 1994.

21.WALKER, M.R.; RAPLEY, R. Guia de rotas na tecnologia do gene. São Paulo: Atheneu Editora, 1999. 